\title{
Echinodermata in ecotoxicological tests: maintenance and sensitivity
}

\author{
Jocássio Batista Soares, Charrid Resgalla Junior
}

\author{
Centro de Ciências Tecnológicas da Terra e do Mar (CTTMar) - Univerdade do Vale do Itajaí (UNIVALI) \\ (Rua Uruguai, 458, Centro, Itajaí, SC. CEP: 88302-901, Brazil) \\ *Corresponding author: cresgalla@univali.br
}

\begin{abstract}
This work investigates the sensitivity of four species of Echinodermata (Lytechinus variegatus, Echinometra lucunter, Arbacia lixula and Encope emarginata), evaluating the effect of five reference toxicants $(\mathrm{Cd}, \mathrm{Pb}, \mathrm{Cr}, \mathrm{Cu}$ and $\mathrm{SDS})$ on embryo-larval development, following the official protocols. It also evaluates techniques for the maintenance of $L$. variegatus in the laboratory, changes in its sensitivity, and the effects of chemical agents that induce the release of gametes, on the survival rates of the organisms. In terms of the maintenance of L. variegatus in the laboratory, the diet with vegetable content appears to be more favorable for maintenance and maturation in cultivation tanks. Chemical inducers such as $\mathrm{KCl}$ and the Anesthetic (lidocaine and epinephrine) resulted in high adult mortality rates, discouraging its re-induction. The tests performed with different species of sea urchin and sand dollar, using different reference toxicants, showed no variations in sensitivity to the more toxic chemicals, indicating that different species can be used for evaluation and environmental impact assessment.
\end{abstract}

Descriptors: Echinodermata, Sensitivity, Chronic Tests, Maintenance, Chemical inducers, Lytechinus variegatus.

\section{Resumo}

O presente trabalho investigou a sensibilidade de quatro espécies de Echinodermata (Lytechinus variegatus, Echinometra lucunter, Arbacia lixula e Encope emarginata), avaliando o efeito de cinco tóxicos de referência $(\mathrm{Cd}, \mathrm{Pb}, \mathrm{Cr}, \mathrm{Cu}$ e $\mathrm{SDS})$ no desenvolvimento embrio-larval, seguindo os protocolos oficiais. Foram avaliadas também técnicas de manutenção de L. variegatus em laboratório, alterações de sua sensibilidade e efeitos de agentes químicos indutores de liberação de gametas nas taxas de sobrevivência dos organismos. Para $L$. variegatus mantido em laboratório, a dieta com conteúdo de vegetais e leguminosas parece ser favorável à manutenção e maturação em tanques de cultivo. Indutores químicos como o $\mathrm{KCl}$ e o Anestésico (lidocaína e epinefrina) ocasionaram altas taxas de mortalidade de adultos, desencorajando sua re-indução. Os ensaios realizados com as quatro diferentes espécies de Echinodermata utilizando variados tóxicos de referência não apresentaram variações de sensibilidade para os químicos de maior toxicidade, indicando que diferentes espécies podem ser utilizadas na avaliação e estudo de impacto ambiental.

Descritores: Echinodermata, Sensibilidade, Ensaios crônicos, Manutenção, Indutores químicos, Lytechinus variegatus. 


\section{INTRODUCTION}

Embryo-larval tests with Echinodermata, called chronic or sub-chronic short-term tests, have been among the most widespread methods worldwide for the analysis of environmental quality since the 1960s, due to their accessibility, speed, and reliability (ENVIRONMENT CANADA, 2011; USEPA, 2002). In Brazil, these marine toxicity tests began at the CETESB (Companhia de Saneamento do Estado de São Paulo - Sanitation Company of the State of São Paulo) at the end of the 1970s, and the protocols developed from the 1990s were adopted as the basis for the standardization by the ABNT (Brazilian Association of Technical Standards) in 2005.

At the meetings of the Special Temporary Study Committee for Ecotoxicological Analyses (ABNT/ CEET), adaptations of the test protocols for chronic marine toxicity tests with sea urchin (Echinodermata) were discussed (NBR/ABNT, 2012). This new Standard marked a certain progress in terms of increasing the number of species that could be used in toxicity tests for regulatory purposes. However, the protocol was restricted to just two species of sea urchin, keeping Lytechinus variegatus and Echinometra lucunter for national use.

Although the species of sea urchins recommended by the ABNT are highlighted by PRÓSPERI and ARAÚJO (2002) as having wide distribution on the Brazilian coast, there have been no studies to date that give an actual diagnosis of the distribution, or data on the sea urchin populations along the Brazilian coast. LAGE et al. (2011) and IHARA et al. (2010) warn of the disappearance of populations of Lytechinus variegatus on the northeastern Brazilian coast, and the same has been suggested for the coast of São Paulo (IBAMA, unpublished data). This information is reflected in the inclusion of Lytechinus variegatus in the list of endangered species in the State of Santa Catarina (CONSEMA, 2011), despite the lack of information to prove the real populational situation in the environment.

The restriction to the use of only two species registered for ecotoxicological tests places greater pressure tending to its removal from the environment. Alongside this is the fact that sea urchins have no apparent sexual dimorphism, which means that for each assay, large numbers of the species are collected and induced, in order to ensure that both gametes are obtained. An aggravating factor for its use in the laboratory is the fact that its survival is not guaranteed after induction by $\mathrm{KCl}$ (HINEGARDNER,
1969; LUIS et al., 2005; GAGO; LUIS, 2011). In any case, this information creates a barrier to the implementation of ecotoxicological tests, demonstrating the limitation in the ABNT protocol that reduces environmental impact studies due to the number of recognized species. In contrast, other Standards recommend the use of species not registered for tests, provided this is done in a preliminary study, evaluating their sensitivity to reference toxicants, with the drawing up of a sensitivity control chart (USEPA, 2002).

The control chart compiles the evaluations of the sensitivity of the test organisms, and is considered an essential method for testing the accuracy and reliability of the data produced in the laboratory (ENVIRONMENT CANADA, 2011) and for assessing the relative sensitivity of a population (GREENBERG et al., 1992). However, the choice of a reference substance or toxicant, among such essential metals as zinc, copper and chromium, which participate in multiple metabolic pathways, make it difficult to compare sensitivity between test organisms, even within a single taxonomic group (MÁXIMO et al., 2008). On the other hand, non-essential reference toxicants, such as SDS (Sodium Dodecyl Sulfate) detergent, cadmium and lead, may present more realistic effects, due to their lower selectivity in terms of harmful action on the biological systems (ABEL, 1989). However, there has been little investigation of this selectivity for different chemicals in marine ecotoxicology. It is only by comparing the behavior of these toxicants in relation to essential metals, normally used as reference toxicants, that it will be possible to confirm the hypothesis that testorganisms of the same taxonomic group do not show differences in sensitivity (ENVIRONMENT CANADA, 2011; HIS et al., 1999).

Thus, some strategies can be applied in the effort to improve the use of Echinodermata in ecotoxicological tests. For the preservation of the species of sea urchins registered for tests, efforts can be made to reduce the collection effort, through their prolonged maintenance in the laboratory, even after their repeated chemical induction. The second strategy would be to investigate the sensitivity of different species of Echinodermata for use in toxicity tests without adversely affecting the impact assessment.

The objective of this study was to evaluate the maintenance of adults of the sea urchin Lytechinus variegatus in the laboratory for long periods, involving their survival after chemical induction, and to evaluate the existence of changes in their sensitivity. The 
existence of variations in sensitivity of different species of Echinodermata with potential use in ecotoxicological chronic embryo-larval tests was investigated, comparing the effects of different reference toxicants, both essential and non-essential metals.

\section{MATERIAL AND METHODS}

Specimens of adult organisms of Echinodermata were obtained by scuba diving, in different localities off the north coast of Santa Catarina State, in order to obtain the different species used in this study. The species Lytechinus variegatus, Arbacia lixula and Echinometra lucunter were collected in the vicinity of Ilha Feia, in the municipality of Penha (2644'41.09'S and 48 $38^{\prime} 13.62$ 'W). The species Encope emarginata was collected within the limits of the Caixa D'aço beach, in the municipality of Porto Belo (27 7'35.69's and 48 31 '34.60' $\mathrm{W})$ and Daniela beach, Florianópolis $\left(27^{\circ} 27^{\prime} 18.16^{\prime \prime S}\right.$ and $\left.48^{\circ} 32^{\prime} 24.35^{\prime} \mathrm{W}\right)$. After collection, the organisms obtained were immediately transported to the Laboratory for Ecotoxicology (LETOX) of CTTMar/ UNIVALI, and placed in 70-liter aquariums with natural seawater, at a temperature of $22 \pm 2{ }^{\circ} \mathrm{C}$ and with a $12: 12$ photoperiod, for brief acclimatization and subsequent use in laboratory tests. Part of the organisms was returned to their place of origin after use, and part were kept in the laboratory for studies of changes in sensitivity and mortality for a maximum period of 90 days.

Only the urchin sea species L. variegatus was used a posteriori and maintained under two different conditions, namely:

1. Maintenance in the laboratory - ML1 - between July and October 2010, 52 specimens of L. variegatus were placed in two 400-liter ellipsoid tanks, equipped with a particulate material filtration system (Atman $\mathrm{II}^{\circledR}$ model EF4000UV and Azoo ${ }^{\circledR}$ model CF1500) and removal of organic matter dissolved by the skimmer system. In this period, a diet based on vegetables (chard and carrots) was given, and a routine of weekly backwashing of the filters was adopted, with complete renewal of the water every 15 days, followed by cleaning of the filters and tanks. These procedures maintained controlled conditions of salinity (31.6 to 35.0$), \mathrm{pH}$ (7.64 to 8.35), and oxygen ( 7.20 to $7.53 \mathrm{mg} \mathrm{L}^{-1}$ ), and a constant temperature of $22 \pm$ $2^{\circ} \mathrm{C}$. Three chemical inductions by $\mathrm{KCl}$ were performed on groups of organisms at time zero (arrival of organisms from the field - 14 organisms), 27 days of maintenance (16 organisms) and 48 days of maintenance (11 organisms), allowing the evaluation of sensitivity tests with reference toxicants, as well as the mortality rate of the groups exposed to chemical induction, compared with a control group without induction. The maximum maintenance time of the organisms was 90 days.

2. Maintenance in the laboratory - ML2 - between May and September 2011, 42 specimens of $L$. variegatus were placed in two 400-liter ellipsoid tanks, under the same conditions as ML1. In this period, a diet based on live food was given (Sargassum $\mathrm{sp}$ ) and feed composed of $30 \%$ dehydrated Sargassum sp, 20\% fish meal $\left(\right.$ Kenya $\left.^{\circledR}\right)$ gelified in a mixture of $10 \%$ Agar dissolved in $50 \%$ seawater. The maintenance routine was modified to a weekly range of backwashing of the filters, complete renewal of the water, and cleaning of the filters and tanks. Under these conditions, salinity was maintained at between 31.7 and 35.4 , pH at between 7.67 and 8.80, and dissolved oxygen at between 6.76 and $7.85 \mathrm{mg} \mathrm{L}^{-1}$ at a temperature of $22 \pm 2{ }^{\circ} \mathrm{C}$. During this period, three monthly chemical inductions were performed, in groups of 10 individuals, on arrival from the field (time 0 ), at 26 days of maintenance, and at 38 days of maintenance, enabling sensitivity to be evaluated in the toxicity tests with the reference toxicants, as well as the mortality rate of the groups exposed to chemical induction with only Anesthetic $\mathrm{L}^{\circledR}$ (lidocaine hydrochloride solution - $2.0 \mathrm{~g}$ in 100 $\mathrm{mL}$ of solution containing $2 \%$ of epinephrine - CLE according to MÁXIMO, personal communication) and a control group without induction. The maximum maintenance time of the organisms was 81 days.

In the laboratory, the embryo-larval toxicity tests with Echinodermata were carried out according to the recommendations of the NBR/ABNT (2012), using gametes of four species of sea urchins: L. variegatus and $E$. lucunter (species registered by the ABNT), $A$. lixula and $E$. emarginata (alternative species). The ovule and sperm of the organisms were obtained through chemical induction by injection of $1 \mathrm{~mL}$ of $\mathrm{KCl}$ solution at $0.5 \mathrm{M}$ in the experiments of all the organisms, and as alternative chemical induction of $1 \mathrm{~mL}$ of anesthetic $\mathrm{L}^{\circledR}$ for the experiments with L. variegatus carried out from May 2011 for its maintenance ML2. After the release of gametes, the ovule were collected in beakers with filtered seawater, and the sperm were collected directly from the genital pores (without dilution in water) and kept cold under ice. 
For the fertilization, a few drops of sperm solution ( $0.5 \mathrm{~mL}$ of sperm in $24.5 \mathrm{~mL}$ of seawater) were added to the containers containing the ovule, and left for about 20 minutes with slight agitation of the gametes. After this period, aliquots of embryos were examined under a stereoscopic microscope for selection of fertilized ovule, following a selection criterion of at least $80 \%$ formation of the fertilization membrane.

The toxicity tests with the reference toxicants were performed in $15 \mathrm{~mL}$ plastic bottles, with $10 \mathrm{~mL}$ of test solution, for 24 hours (with the exception of E. lucunter which was performed in 36 hours), at a temperature of 25 $\pm 2^{\circ} \mathrm{C}$ and photoperiod of $12: 12$. The reference toxicants were used in six concentrations plus control, and in four replicates for each concentration. After the exposure period, the test flasks were fixed with the addition of $4 \%$ formol and the larvae were analyzed under a binocular microscope, with the aid of a Sedgewick-Rafter chamber. A total of 100 larvae were quantified, including both normal larvae and those with delayed development or malformation, to estimate the percentages of effect.

The reference toxicants used in this study were Sodium Dodecyl Sulphate detergent (SDS - Merck $^{\circledR}$ ), Cadmium chloride $\left(\mathrm{CdCl}_{2}-\mathrm{Sigma}^{\mathbb{R}}\right)$, standard metallic solution for atomic absorption of Lead $\left(\operatorname{Merck}^{\circledR}\right)$, Potassium Dichromate $\left(\mathrm{K}_{2} \mathrm{Cr}_{2} \mathrm{O}_{7}-\mathrm{Merck}^{\circledR}\right)$, and Copper sulphate pentahydrate $\left(\mathrm{CuSO}_{4} \cdot 5 \mathrm{H}_{2} \mathrm{O}-\mathrm{Merck}^{\circledR}\right)$. With the percentages of effect, the $\mathrm{EC}_{50}$ (Median Effective Concentration) values were estimated by the nonparametric Trimmed Spearman-Karber method (USEPA, 2002). For the organisms maintained in the laboratory (ML1 and ML2) only tests with the toxicants SDS and potassium dichromate were performed.

\section{RESULTS}

\section{SEnsitivity OF L. VARIEGATUS}

The embryo-larval tests of $L$. variegatus, when compared with different reference toxicants, demonstrated the formation of two distinct toxicity groups, with $\mathrm{Cu}$ and $\mathrm{Pb}$ being the most toxic substances, and with greater variability of results (coefficient of variation - CV between 34.41 and $45.14 \%$ ) and SDS, Cr and Cd were less toxic, with less variability of results (coefficient of variation CV between 5.21 and 34.22\%) (Table 1 and Figure 1). The variability observed is not related to the number of tests performed, but to the range of concentration obtained for each group of chemicals.
Table 1. Number of tests $(\mathrm{N})$, mean values and standard deviation (SD) of $\mathrm{EC}_{50}\left(\mu \mathrm{g} \mathrm{L}^{-1}\right)$ and coefficient of variation $(\mathrm{CV})$ of the reference toxicants for the embryo-larval tests of Lytechinus variegatus.

\begin{tabular}{lcccc}
\hline $\begin{array}{l}\text { References } \\
\text { toxicants }\end{array}$ & $\mathrm{N}$ & $\begin{array}{c}\text { mean } \\
\mathrm{EC}_{50}\end{array}$ & $\mathrm{SD}$ & $\mathrm{CV}$ \\
\hline $\mathrm{Cu}$ & 5 & 19.30 & 6.62 & 34.31 \\
$\mathrm{~Pb}$ & 5 & 102.00 & 46.04 & 45.14 \\
$\mathrm{SDS}$ & 6 & $1,598.33$ & 546.97 & 34.22 \\
$\mathrm{Cr}$ & 6 & $2,463.84$ & 128.24 & 5.21 \\
$\mathrm{Cd}$ & 3 & $5,275.58$ & 924.48 & 17.52 \\
\hline
\end{tabular}

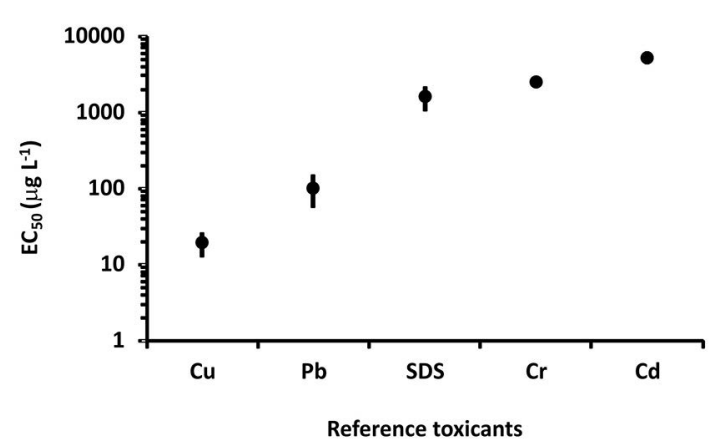

Figure 1. Mean values (dot) and standard deviation (bar) of reference toxicants $\left(\mu \mathrm{g} \mathrm{L}^{-1}\right)$ in embryo-larval tests of Lytechinus variegatus.

\section{MAINTENANCE IN THE LABORATORY, INDUCTORS AND MORTALITY}

The attempt to maintain sea urchins of the species L. variegatus proved laborious due to the maintenance of water quality and the supply of food. In any event, in both maintenance systems, the mortalities observed in the control organisms (without induction of spawning) were restricted to a maximum percentage of $10 \%$, indicating appropriate conditions for survival for the renewal of water and composition of the diet.

In terms of chemical inducers used in the adults, Anesthetic $L^{\circledR}$ apparently showed the highest power of induction of organisms (Table 2) in comparison with $\mathrm{KCl}$. On the other hand, it showed a tendency to result in higher mortality rates after induction (from 13 to $36 \%$ of mortality for $\mathrm{KCl}$ and from 10 to $40 \%$ for Anesthetic $\mathrm{L}^{\circledR}$ ) (Figure $2 \mathrm{a}$ and $\mathrm{b}$ ). In terms of sensitivity, it is suggested that only in maintenance ML2 was a change observed in the pattern of the organisms at 38 days of maintenance, both for $\mathrm{Cr}$ and for SDS (Figure 2c, d, e and f). The results showed no relationship between changes in sensitivity of the organisms with the rates of mortality observed after chemical induction. 
Table 2. Percentage of organisms of the species $L$. variegatus with release of gametes by inductor chemical in specimens in maintenance tanks.

\begin{tabular}{lcccc}
\hline $\begin{array}{l}\text { Maintenan- } \\
\text { ce in the } \\
\text { laboratory }\end{array}$ & $\begin{array}{c}\text { Induction } \\
\text { substance }\end{array}$ & $\begin{array}{c}\text { No. of } \\
\text { organisms }\end{array}$ & $\begin{array}{c}\text { Release } \\
\text { of game- } \\
\text { tes (\%) }\end{array}$ & $\begin{array}{c}\text { Maintenan- } \\
\text { ce period } \\
\text { (days) }\end{array}$ \\
\hline \multirow{3}{*}{ ML1 } & $\mathrm{KCl}$ & 16 & 14.3 & 0 \\
& & 11 & 12.5 & 27 \\
\multirow{2}{*}{ ML2 } & $\begin{array}{c}\text { Anesthe- } \\
\text { tic L }{ }^{\circledR}\end{array}$ & 10 & 90.0 & 48 \\
& & 10 & 20.0 & 26 \\
& & & & \\
& & & & \\
\end{tabular}
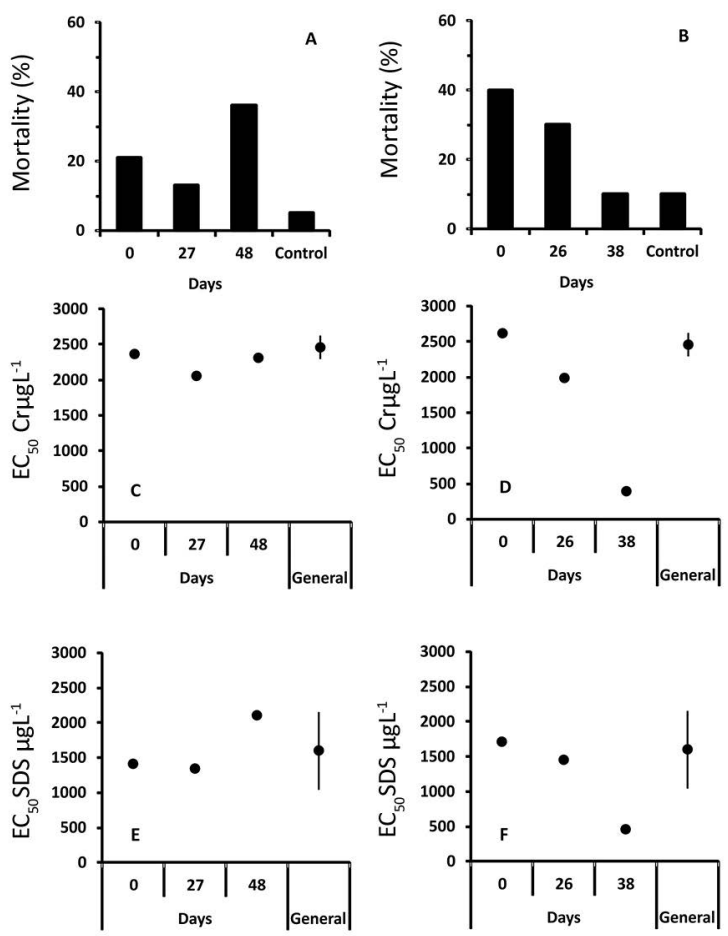

Figure 2. Mortality rates (\%) of L. variegatus after induction (ML1 - KCl, ML2 - Anesthetic L) and maintenance time, and of organisms not induced (control) in cultivation tanks under conditions ML1 (A) and ML2 (B). $\mathrm{EC}_{50}$ values ( $\left.\mu \mathrm{g} \mathrm{L}^{-1}\right)$ for $\mathrm{Cr}(\mathrm{C}$ and $\mathrm{D})$ and SDS (E and F) by maintenance time, under conditions ML1 (C and E) and ML2 (D and F) as well as the mean value (dot) and standard deviation (bar) of the $\mathrm{EC}_{50}\left(\mu \mathrm{g} \mathrm{L}^{-1}\right)$ of $\mathrm{Cr}$ and SDS of organisms obtained in nature (General).

\section{Comparison of Sensitivity of the SPeCIES OF}

\section{ECHINODERMATA}

The results of tests using different species of Echinodermata showed, in general, little variation in sensitivity. Only for $\mathrm{Cd}$ was there formation of groups of distinct sensitivity, consisting of E. lucunter and $E$. emarginta with an average $\mathrm{EC}_{50}$ of $357.19 \mu \mathrm{g} \mathrm{L}^{-1}$ and $A$. lixula and $L$. variegatus with an average $\mathrm{EC}_{50}$ of $4,790.13$ $\mu \mathrm{g} \mathrm{L}^{-1}$ indicating a greater range of variation in sensitivity (different orders of magnitude), in relation to the other toxicants tested (Figure 3 and Table 3).

\section{DISCUSSION}

The capacity of a substance to be little or very toxic is usually associated with the existence of specific sites of action. For the sea urchin $L$. variegatus, the metals $\mathrm{Cu}$ and $\mathrm{Pb}$ are presented as the most toxic and, regardless of whether or not the metal is essential, this characteristic is suggested to have little importance in the toxicity tests of embryonic development. Normally, non-essential metals present greater toxicity, because they can compete or conjugate with essential metals, leading to toxicity in metabolic interactions, particularly in the skeletal constitution of organisms and effects on the nervous system (GOYER, 1997). According to ABEL (1989) the order of decreasing toxicity for heavy metals in aquatic organisms is mercury $>$ cadmium $>$ copper $>$ zinc $>$ nickel $>$ lead $>$ chromium $>$ aluminium $>$ cobalt. However, the toxicity of a given metal can vary greatly from one species to another, depending on various physiological/ biochemical factors.

On the other hand, the intermediate toxicity presented by the SDS detergent shows the wide variation of concentrations of effect recorded for this chemical group ( 0.4 to $40 \mathrm{mg} \mathrm{L}^{-1}$ ). Synthetic detergents normally present action on the proteins of the membranes, altering their permeability and consequently affecting the gills, causing developmental delay in the embryo and larval stage, and causing changes in feeding behavior, as well as effects on the chemoreceptor organs (ABEL, 1974).

Few studies have reported the ideal conditions for the cultivation of adult sea urchin in the laboratory. For commercial production of Strongylocentrotus droebachiensis, SIIKAVUOPIO (2012) highlights the conditions of maintenance at a density of below $6 \mathrm{~kg}$ $\mathrm{m}^{-2}$ which was applied in this study. Both forms of maintenance demonstrate abiotic conditions within the acceptable range by species. According to WATTS et al. (2007) the minimum and maximum acceptable values of the salinity for $L$. variegatus are from 20 to 35 and 11$35^{\circ} \mathrm{C}$ for temperature.

A successful maintenance should also combine a balanced diet with the needs of the organisms. According 

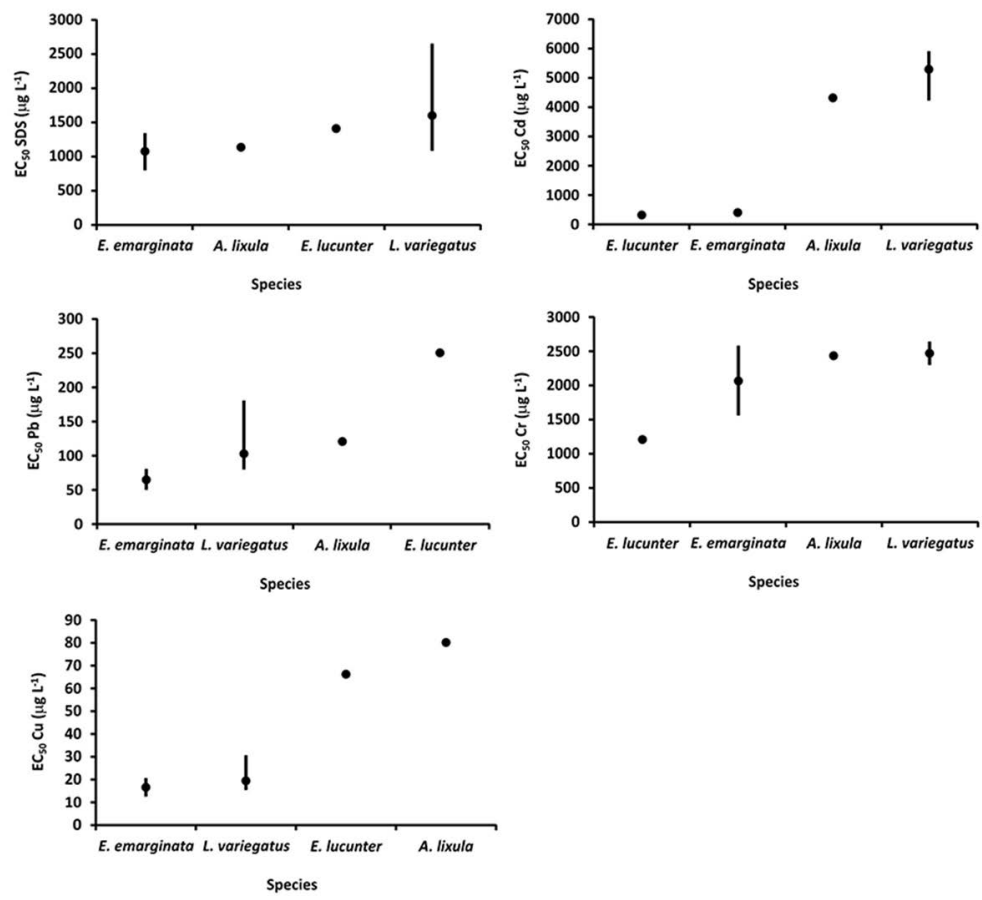

Figure 3. Minimum, maximum and mean $\mathrm{EC}_{50}\left(\mu \mathrm{g} \mathrm{L} \mathrm{L}^{-1}\right)$ for different reference toxicants in assays using different species of Echinodermata.

Table 3. Number of tests $(\mathrm{N})$ and $\mathrm{EC}_{50}\left(\mu \mathrm{g} \mathrm{L}^{-1}\right)$ values for the reference toxicants for tests with different species of Echinodermata.

\begin{tabular}{lcccccc}
\hline Species & $\mathrm{N}$ & $\mathrm{SDS}$ & $\mathrm{Cd}$ & $\mathrm{Pb}$ & $\mathrm{Cr}$ & $\mathrm{Cu}$ \\
\hline $\begin{array}{l}\text { A. lixula } \\
\begin{array}{l}\text { E. emargi- } \\
\text { nata* }\end{array}\end{array}$ & 1 & 1130.00 & 4304.68 & 120.00 & 2428.44 & 80.00 \\
$\begin{array}{l}\text { E. } \\
\text { lucunter }\end{array}$ & 1 & 1410.00 & 312.73 & 250.00 & 1203.60 & 66.04 \\
\hline * & & 401.65 & 65.00 & 2062.05 & 16.51 \\
\end{tabular}

* average values

to WATTS et al. (2007) the species L. variegatus demonstrates omnivorous habits, feeding in nature on a wide range of foods, including microalgae, marine grasses and molluscs. Because it presents a varied diet, there have been few studies for the establishment of a balanced diet that presents the best stability for animal development. However, studies have demonstrated a favorable relationship with development and growth, with diets supplemented with high concentrations of protein (HAMMER et al., 2006; GIBBS et al., 2009; PEARCE et al., 2002), but these studies do not evaluate the embryonic potential of the animal.

On the other hand, an unfavorable relationship with development and growth is described with the diet rich in fibers and complex sugars, which may not be digested by sea urchins (KLINGER, 1984). Alongside this, studies on energy use of individuals of $62 \mathrm{~mm}$ diameter fed on algae resulted in $6.7 \%$ efficiency in the production of gonads (MOORE et al., 1963). In addition to this low utilization of algae, studies on the feeding habits of L. variegatus performed by LIMA et al. (2008) identified secondary metabolites associated with the defense mechanism against herbivory present in algae, which act as growth modulators of the species. However, secondary metabolites, more specifically carotenoids, are more abundant pigments in the embryonic tissues (TSUSHIMA, 2007), reinforcing the importance of this kind of food for the development of the organism.

In the present study, the different forms of maintenance tested (ML1 and ML2) showed adult survival rates of over $90 \%$, indicating conditions of cultivation of the organisms. However, for ML2, the increase in sensitivity of the embryo-larval test at 38 days of maintenance suggests that the growth of the gonads was not affected by the concentration of protein, but was probably affected by the protein origin of the food (PEARCE et al., 2002) since the food was offered in abundance. This fact casts doubt as to whether a fish-based diet would be duly balanced, based on the results of the ecotoxicological tests.

On the other hand, the mortality rates recorded are associated with chemical inductions applied to the obtaining of gametes. High mortality rates for the sea 
urchin Paracentrotus lividus induced by injection of 1 $\mathrm{mL}$ of $\mathrm{KCl}$ to $0.5 \mathrm{M}$ have been reported by LUIS et al. (2005) and GAGO and LUIS (2011). The same result was obtained in the present study, and the alternative use of Anesthetic $\mathrm{L}^{\circledR}$, which despite presenting higher efficiency in the spawning of the organisms, presented mortality rates equal to or greater than $\mathrm{KCl}$. In any event, the mortality rates observed (up to $40 \%$ ) discourage the reinduction of the organisms, and further studies are needed to evaluate the impact of this activity on the survival and natural populations of sea urchins.

The need for standardization of the ecotoxicological tests can be justified due to the requirement of reproducibility of results that can be achieved by different laboratories. This standardization can be achieved based on the methods and the species of test organism used (USEPA, 2002). Once a standard has been determined, a deviation in its application is often limited to the interpretation of the environmental body responsible.

In ecotoxicology, the choice of test organisms, in particular, has always been a subject of debate, and decisions are often made in the most convenient way, due to the limited availability of information on the real implications of decision-making on the environmental impact assessment.

Despite the low number of tests carried out on species of echinodermatas other than L. variegatus, the values obtained are within the range of variation and/or of the same order of magnitude observed by other authors who investigated the sensitivity of $A$. lixula (RESGALLA JÚNIOR; LAITANO, 2002; MÁXIMO et al., 2008; RESGALLA et al., 2012), E. lucunter (RUMBOLD; SNEDAKER, 1997; RESGALLA JÚNIOR; LAITANO, 2002) and the sand dollar Mellita quinquiesperforata (LAITANO et al., 2008), which validate the results obtained in this work. On the basis of this, it was suggested that the different species tested have similar sensitivity, or order of sensitivity to the different metals tested, whether essential or non-essential. Based on the toxicity gradient $(\mathrm{Cu}$ and $\mathrm{Pb}>\mathrm{SDS}$ and $\mathrm{Cr}$ and $\mathrm{Cd})$ the metals $\mathrm{Cu}$ and $\mathrm{Pb}$ were found to be the most toxic to all the species tested, indicating, in this case, an absence of differences between the species tested. The other chemicals, Cr, Cd and SDS (detergent), which were the toxicants with less effect and therefore of lesser importance for classifying the species investigated, indicated similarity of $A$. lixula with $L$. variegatus and of E. lucunter with E. emarginata.
This downward trend of differences in sensitivity in Echinodermata has already been highlighted by other studies in Brazil involving different test organisms (RESGALLA JÚNIOR; LAITANO, 2002; MÁXIMO et al., 2008; LAITANO et al., 2008). Associated with this, HIS et al. (1999), in studies on tests with molluscs, also emphasize that species with distinct ecological and phylogenetic characteristics may respond similarly to some toxicants. The same has been highlighted by ENVIRONMENT CANADA (2011) for Echinodermata.

The two species standardized by NBR/ABNT (2012), L. variegatus and E. lucunter, are present in distinct groups of Echinodermata in relation to their sensitivity, based on the second level of toxicity of the chemicals used in this study (metal lower toxicity). This fact is likely to lead to misinterpretation of the results obtained in the tests, and is dependent on the choice of the species used as test organisms. However, comparisons of the results of ecotoxicological evaluations may not show any differences when the chemical being assessed is more toxic.

Concluding, in terms of the maintenance of $L$. variegatus in the laboratory, the diet with high content of animal protein indicated changes in sensitivity of the organisms for toxicity tests in long-term maintenance ( $>$ 30 days). Feed with vegetable content appears to be more favorable to maintenance and maturation in cultivation tanks.

Chemical inducers such as $\mathrm{KCl}$ and the Anesthetic $\mathrm{L}^{\circledR}$ resulted in high mortality rates of $L$. variegatus (up to $40 \%$ ), discouraging its re-induction. Studies on alternatives for obtaining gametes and their impacts on the natural populations of this species are urgently needed.

The tests performed with the different species of sea urchin and sand dollar with different reference toxicants did not demonstrate variations for chemicals with higher toxicity, indicating that different species can be used in the evaluation and study of environmental impact, and that the NBR/ABNT (2012) can be extended to other species of Echinodermata.

\section{ACKNOWLEDGMENTS}

The authors are grateful to the Superintendence of the Port of Itajai for the financial support provided through the Monitoring Program of the Itajaí-açu river Port Region, and to the CNPq for research grant PQ Process 305910/2011-6. 


\section{REFERENCES}

ABEL, P. D. Toxicity of synthetic detergents to fish and aquatic invertebrates. J. Fish. Biol., v. 6, n. 3, p. 279-298, 1974.

ABEL, P. D. Water pollution biology. Chichester: Ellis Horwood Limited, 1989.

CONSEMA (Conselho Estadual do Meio Ambiente - Secretaria de Estado do Desenvolvimento Econômico Sustentável). Resolução CONSEMA N ${ }^{\circ}$ 002, de 06 de dezembro de 2011. Reconhece a Lista Oficial de Espécies da Fauna Ameaçadas de Extinção no Estado de Santa Catarina e dá outras providências. Disponível em: <http://www.fatma.sc.gov.br>. Acesso em: 2011.

ENVIRONMENT CANADA. Biological test method: fertilization assay using echinoids (sea urchins and sand dollars). Environmental Protection Series. EPS 1/RM/27 Second Edition. Ottawa: Environment Canada; 2011.

GAGO, J.; LUIS, O. J. Comparison of spawning induction techniques on Paracentrotus lividus (Echinodermata: Echinoidea) broodstock. Aquacult. Int., v. 19, n. 1, p. 181-191, 2011.

GIBBS, V. K.; WATTS, S. A.; LAWRENCE, A. L.; LAWRENCE, J. M. Dietary phospholipids affect growth and production of juvenile sea urchin Lytechinus variegatus. Aquaculture, v. 292, n. 1/2, p. 95-103, 2009.

GOYER, R. A. Toxic and essential metal interactions. Annu. Rev. Nutr., v. 17, p. 37-50, 1997.

GREENBERG, A. E.; CLESCERI, L. S.; EATON, A. D. Standard methods for the examination of water and wastewater. 18th ed. Washington: American Public Health Association, 1992.

HAMMERA, H.; WATTS, S.; LAWRENCE, A.; LAWRENCE, J.; DESMOND, R. The effect of dietary protein on consumption, survival, growth and production of the sea urchin Lytechinus variegatus. Aquaculture, v. 254, n. 1/4, p. 483-495, 2006.

HINEGARDNER, R. T. Growth and development of the laboratory cultured sea urchin. Biol. Bull., v. 137, n. 3, p. 465-475, 1969.

HIS E.; BEIRAS, R.; SEAMAN, M. N. L. The assessment of marine pollution - bioassays with bivalve embryos and larvae. Adv. Mar. Biol., v. 37, p. 1-178, 1999.

IHARA, P. M.; PINHO, G. L. L.; FILLMANN, G. Avaliação do Copépodo Acartia tonsa (Dana, 1849) como organismo-teste para ensaios de toxicidade crônica. J. Braz. Soc. Ecotoxicol., v. 5, n. 1, p. 27-32, 2010.

KLINGER, T. S. Activities and kinetics of digestive $\alpha$ - and $\beta$-glucosidaseand $\beta$-galaetosidase of five species of echinoids (Echinodermata). Comp. Biochem. Physiol. A Physiol., v. 78, n. 3, p. 597-600, 1984.

LAGE, A. M. C.; JOYEUX, J. C.; GOMES, L. C. Reprodução de Lytechinus variegatus (Echinodermata: Echinoidea): efeito do ciclo lunar e características da população. Acta Sci. Biol. Sci., v. 33, n. 3, p. 341-346, 2011.

LAITANO, K. S.; GONÇALVES, C.; RESGALLA JÚNIOR, C. Viabilidade do uso da bolacha-do-mar Mellita quinquiesperforata como organismo teste. J. Braz. Soc. Ecotoxicol., v. 3, n. 1, p. 9-14, 2008.
LIMA, L. M. S.; ALOR, R.; URIOSTEGUI, R.; MURRAY, S. N.; PEREIRA, R. C. Within-plant variation in palatability and chemical defenses in the green seaweed Avrainvillea elliottii. Bot. Mar., v. 51, n. 1, p. 21-25, 2008.

LUIS, O.; DELGADO, F.; GAGO, J. Year-round captive spawning performance of the sea urchin Paracentrotus lividus: Relevance for the use of its larvae as live feed. Aquat. Living Resour., v. 18, n. 1, p. 45-54, 2005.

MÁXIMO, M. V.; MOTTOL, L. S. M.; RESGALLA JÚNIOR, C. Sensibilidade do ouriço Arbacia lixula (Echinodermata: Echinoidea) em testes de toxicidade. J. Braz. Soc. Ecotoxicol., v. 3 , n. 1, p. 47-52, 2008.

MOORE, H. B.; JUTARE, T.; BAUER, J. C.; JONES, J. A. The biology of Lytechinus variegatus. Bull. Mar. Sci. Gulf Carib., v. 13, p. 23-53, 1963.

NBR/ABNT (Associação Brasileira de Normas Técnicas). ABNT NBR 15350 Ecotoxicologia aquática: Toxicidade crônica de curta duração - Método de ensaio com ouriço-do-mar (Echinodermata: Echinoidea). NBR/ABNT, 2012. 17 p.

PEARCE, C. M.; DAGGETT, T. L.; ROBINSON, S. M. C. Effect of protein source ratio and protein concentration in prepared diets on gonad yield and quality of the green sea urchin, Strongylocentrotus droebachiensis. Aquaculture, v. 214, n. 1/4, p. 307-332, 2002.

PRÓSPERI, V. A.; ARAÚJO, M. M. S. Teste de toxicidade crônica de curta duração com Lytechinus variegatus Lamarck 1816 e Echinometra lucunter, Linnaeus 1758 (Echinodermata: Echinoidea). In: NASCIMENTO, I. A.; SOUSA, E. C. P. M.; NIPPER, M. (Eds.). Métodos em ecotoxicologia marinha: Aplicações no Brasil. São Paulo: Artes Gráficas e Indústria Ltda, 2002. p. 99-110.

RESGALLA JÚNIOR, C.; LAITANO, K. S. Sensibilidade dos organismos marinhos utilizados em testes de toxicidade no Brasil. Notas Téc. Facimar, v. 6, p. 153-163, 2002.

RESGALLA JÚNIOR, C.; POLEZA, F.; SOUZA, R. C.; MÁXIMO, M. V.; RADETSKI, C. M. Evaluation of effectiveness of EDTA and sodium thiosulfate in removing metal toxicity toward sea urchin embryo-larval applying the TIE. Chemosphere, V. 89, n. 1, p. 102-107, 2012.

RUMBOLD, D. G.; SNEDAKER, S. C. Evaluation of bioassays to monitor surface microlayer toxicity in tropical marine waters. Arch. Envir. Cont. Toxicol., v. 32, n. 2, p. 135-140, 1997.

SIIKAVUOPIO, S. I. Effects of Hyperoxic Conditions on Growth Performance in Juvenile and Adult Green Sea Urchin, Strongylocentrotus droebachiensis. J. World Aqu. Soc., v. 43, n. 4, p. 579-584, 2012.

TSUSHIMA, M. Carotenoids in sea urchins. In: LAWRENCE, J. M. (ed.). Edible Sea Urchins: Biology and Ecology. Amsterdam: Elsevier Science, 2007, p. 159-166.

USEPA (United States Environmental Protection Agency). Short-term methods for estimating the chronic toxicity of effluents and receiving waters to freshwater organisms. EPA-821-R-02-013. Washington: USEPA, 2002. $317 \mathrm{p}$.

WATTS, S. A.; MCCLINTOCK, J. B.; LAWRENCE, J. M. Ecology of Lytechinus. In: LAWRENCE, J. M. (Ed.). Edible sea urchins: biology and ecology. Amsterdam: Elsevier Press, 2007. p. 473-497. 